\title{
ZNACZENIE KONSULTACJI SPOŁECZNYCH W PROCESACH REWITALIZACJI OBSZARÓW MIEJSKICH
}

\section{WSTĘP}

Współczesne podejście do planowania rozwoju i rewitalizacji obszarów miejskich wymaga włączenia i zaangażowania społeczności lokalnej w sprawy przyszłości jej lokalnego środowiska. Znaczenie partycypacji obywatelskiej dla rozwoju lokalnego jest silnie akcentowane w wielu tendencjach, poglądach i modelach dotyczących rozwoju i przyszłości miast. Wśród nich można wyróżnić europejską wizję zrównoważonych miast, nowy model miasta europejskiego koncentrujący się na mieście spójnym, miasto kreatywne i model projektowania struktur przestrzenno-funkcjonalnych miast zwiazany z nowym urbanizmem i inne ${ }^{1}$. Rewitalizacja obszarów miejskich związana ściśle z procesem reurbanizacji jest jedną z ważnych tendencji rozwojowych miast okresu poindustrialnego ${ }^{2}$.

Współcześnie rewitalizacja oznacza planowane działanie, którego celem jest zmiana struktury przestrzenno-funkcjonalnej zdegradowanych obsza-

\footnotetext{
${ }^{1}$ Nowa Karta Ateńska, 2005; J. Parysek, Miasta polskie na przełomie XX i XXI wieku. Rozwój i przekształcenia strukturalne, Bogucki Wydawnictwo Naukowe, Poznań 2005; Karta Lipska na rzecz zrównoważonego rozwoju miast europejskich, 2007; L. Mierzejewska, Zrównoważony rozwój miasta: aspekty planistyczne, w: J. Parysek, A. Tölle (red.), Wybrane problemy rozwoju i rewitalizacji miast: aspekty poznawcze i praktyczne, Biuletyn Instytutu Geografii Społeczno-Ekonomicznej i Gospodarki Przestrzennej UAM, Seria: Rozwój Regionalny i Polityka Regionalna 5, Bogucki Wydawnictwo Naukowe, Poznań 2008, s. 49-71; L. Mierzejewska, Smart growth jako model rozwoju miasta, w: J. Słodczyk, M. Śmigielska (red.), Wspótczesne kierunki i wymiary procesów urbanizacji, UO, Opole 2008, s. 49-65; Karta Nowej Urbanistyki, „Urbanista” 2005, nr 6, s. 8-10.

${ }^{2}$ S. Kaczmarek, Rewitalizacja terenów poprzemystowych: nowy wymiar $w$ rozwoju miast, Wyd. UŁ, Łódź 2001; A. Baranowski (red.), Rewitalizacja zdegradowanych struktur osadniczych $w$ warunkach zrównoważonego rozwoju, Projekt badawczy nr 7507F01112, Komitet Badań Naukowych, Wydział Architektury Politechniki Gdańskiej, Gdańsk 2001; T. Kaczmarek, Rewitalizacja miast $w$ Polsce na tle doświadczeń europejskich, w: A. Billert (red.), Nowoczesne zarzqdzanie rozwojem miast, Collegium Polonicum, Słubice 2001, s. 106-114; I. Behr et al. (red.), Podręcznik rewitalizacji. Zasady, procedury $i$ metody działania wspótczesnych procesów rewitalizacji, Mefisto, Urząd Mieszkalnictwa i Rozwoju Miast, Warszawa 2003; A. Billert, Rewitalizacja i rozwój miast $w$ Polsce - uwarunkowania i scenariusze $w$ świetle doświadczeń europejskich, w: Rewitalizacja miast $w$ Polsce. Pierwsze doświadczenia, Biblioteka Urbanisty 10, Warszawa 2007, s. 92-105; J. J. Parysek, P. Lorens (red.), Urbanizacja i niektóre wspótczesne idee, koncepcje i modele planowania rozwoju miast, w: J. Słodczyk, M. Śmigielska (red.), op. cit., s. 11-27.
} 
rów miejskich oraz ożywienie społeczno-gospodarcze ${ }^{3}$. W istocie chodzi o „[...] skoordynowany proces, prowadzony wspólnie przez władzę samorządowa, społeczność lokalną i innych uczestników, będący elementem polityki rozwoju i majacy na celu przeciwdziałanie degradacji przestrzeni zurbanizowanej i zjawiskom kryzysowym, pobudzanie rozwoju i zmian jakościowych poprzez wzrost aktywności społecznej i gospodarczej, poprawę środowiska zamieszkania, oraz ochronę dziedzictwa narodowego, z zachowaniem zasad zrównoważonego rozwoju [...]"4.

Zgodnie z powszechnie akceptowanym w Unii Europejskiej modelem rewitalizacji i prowadzoną obecnie polityką rewitalizacji w krajach europejskich procesy rewitalizacyjne wymagają szerokiego udziału i współdziałania różnych grup zainteresowania oraz popularyzacji inicjatyw lokalnych społeczności. Partycypacyjne podejście do rewitalizacji jest szczególnie ważne dla terenów nadrzecznych, gdyż pełnią one wiele użytecznych i ważnych społecznie funkcji. Tereny te wymagaja dobrze zaprojektowanych i zagospodarowanych miejsc, które odpowiadaja potrzebom i oczekiwaniom społecznym. Jest to sprawa istotna, biorąc pod uwagę fakt, że w gruncie rzeczy chodzi o lokalne środowisko życia człowieka.

Ważną rolę w odniesieniu do problematyki rewitalizacji terenów nadrzecznych, podobnie jak każdej innej związanej z zagospodarowaniem przestrzennym, pełnią konsultacje społeczne, których celem powinno być określenie potrzeb i oczekiwań społeczności lokalnej, na podstawie których wyznaczone zostana kierunki rozwoju i zagospodarowania tych terenów. W artykule zaprezentowano wyniki konsultacji społecznych dotyczących rewitalizacji miejskich terenów nadrzecznych w Bydgoszczy, które przeprowadzone zostały w ramach badań społecznych dla rewitalizacji tych terenów w pracy doktorskiej autorki Tereny nadrzeczne w strukturze przestrzenno-funkcjonalnej Bydgoszczy. Problemy rozwoju i rewitalizacji ${ }^{5}$.

\section{KONSULTACJE SPOLECZNE W PLANOWANIU ROZWOJU I REWITALIZACJI OBSZARÓW MIEJSKICH}

Współczesne, zintegrowane planowanie rozwoju miasta wymaga zaangażowania w te procesy społeczności lokalnej, umożliwia bowiem obywatelom aktywne uczestniczenie w kształtowaniu ich bezpośredniego środowiska życia, co

${ }^{3}$ P. Lorens, Rewitalizacja miast planowanie i realizacja, Wydział Architektury Politechniki Gdańskiej, Gdańsk 2010; P. Lorens, Wspótczesne tendencje rozwoju struktur miejskich. Znaczenie procesów przekształceń i rewitalizacji, w: P. Lorens, J. Martyniuk-Pęczek (red.), Wybrane zagadnienia rewitalizacji miast, Wydawnictwo Urbanista, Gdańsk 2009, s. 10-19.

${ }^{4}$ Z. Ziobrowski, Cele i efekty projektu, w: Rewitalizacja miast polskich jako sposób zachowania dziedzictwa materialnego $i$ duchowego oraz czynnik zrównoważonego rozwoju. Podsumowanie projektu, Instytut Rozwoju Miast, 2010, Kraków, s. 8-20.

${ }^{5}$ D. Muszyńska-Jeleszyńska, Tereny nadrzeczne $w$ strukturze przestrzenno-funkcjonalnej Bydgoszczy. Problemy rozwoju i rewitalizacji, praca doktorska, Uniwersytet im. Adama Mickiewicza w Poznaniu, Poznań 2012. 
jest zgodne z dokumentami Unii Europejskiej w zakresie planowania rozwoju miast ${ }^{6}$. Dokumenty te podkreślają konieczność powstania nowych systemów reprezentacji i partycypacji oraz większego zaangażowania aktywnych obywateli i różnych grup użytkowników miasta w miejscowe procesy decyzyjne. Jednym z podstawowych wyzwań, przed którymi stoją miasta europejskie, jest unowocześnienie funkcjonowania demokracji lokalnej, poszukiwanie nowych dróg zwiększenia udziału społecznego i uczestnictwa wszystkich podmiotów w celu zabezpieczenia wspólnych interesów ${ }^{7}$.

$\mathrm{W}$ procesach rewitalizacji miasta oraz $\mathrm{w}$ planowaniu przestrzennym uczestnictwo społeczne jest szczególnie ważne, gdyż interesy społeczne określane sa przez różne grupy mające różnorodne potrzeby. W demokratycznych społecznościach partycypacja społeczna powinna odgrywać dużą rolę już na etapie planowania, tak aby sformułowana koncepcja zagospodarowania przestrzennego odpowiadała potrzebom i oczekiwaniom mieszkańców ${ }^{8}$. Jednym z celów właściwie rozumianej partycypacji społecznej w procesie planowania rozwoju i rewitalizacji przestrzeni miejskiej jest kreowanie najkorzystniejszego zagospodarowania dla danego obszaru. Kształt i forma współczesnej przestrzeni miejskiej muszą być uzgadniane zgodnie z zasadami zrównoważonego rozwoju oraz faktycznymi i prawnymi interesami społecznymi, pomiędzy interesem inwestora a dobrem publicznym.

Wymiar społeczny procesów rewitalizacji opiera się na założeniu, że społeczeństwo jest jednocześnie podmiotem i uczestnikiem procesu rewitalizacji. Dotyczy to podniesienia poziomu życia, stworzenia lepszych i atrakcyjnych warunków mieszkania, korzystania z usług i wypoczynku, zachowania społecznej różnorodności użytkowników przestrzeni, kształtowania interesujących dla współczesnego odbiorcy przestrzeni publicznych oraz zachowania i ochrony zasobów dziedzictwa kulturowego. Aspekt ten ma także związek z aktywizacją mieszkańców rewitalizowanych obszarów i włączenie ich w działania rewitalizacyjne.

W procesie planowania rozwoju i rewitalizacji powinny być przeprowadzane dyskusje problemowe, fora dyskusyjne, dialog i wymiana myśli, warsztaty oraz otwarte spotkania, w które zaangażowani są mieszkańcy, przedstawiciele instytucji i podmiotów gospodarczych działających na terenie miasta oraz zaproszeni specjaliści (architekci, planiści i inni). Jedną z form dialogu ze społecznością lokalną w procesach planistycznych sa konsultacje obejmujące badania opinii publicznej, społecznej oraz różnego rodzaju spotkania informacyjne. Efektem debat powinno być sformułowanie problemów, ustalenie hierarchii oraz uzyskanie konsensusu w sprawie sposobu rozwiązania tych problemów9.

${ }^{6}$ Karta Lipska na rzecz zrównoważonego rozwoju miast europejskich, op. cit.; Nowa Karta Ateńska, op. cit.

7 Nowa Karta Ateńska, op. cit.

8 J. Parysek, Gospodarka przestrzenna i rola partycypacji społecznej $w$ procesie planowania przestrzennego, w: K. Ratajczak et al., Gospodarka przestrzenna społeczeństwu, t. 1, Bogucki Wydawnictwo Naukowe, Poznań 2010, s. 79-99.

9 J. Parysek, op. cit. 
Przygotowanie kompleksowej koncepcji działań rozwojowych i rewitalizacyjnych, w tym sposobu zagospodarowania danego obszaru, szczególnie terenów nadrzecznych, wymaga opinii i akceptacji mieszkańców z uwagi na funkcje społeczne (rekreacyjne, wypoczynkowe, przestrzenie publiczne, mieszkaniowe i przyrodnicze), jakie te tereny moga pełnić, zaspokajając zróżnicowane, współczesne potrzeby mieszkańców. W podejmowanych działaniach rewitalizacyjnych winien być opracowany pożądany i akceptowany społecznie model użytkowania terenów nadrzecznych, który zostanie uwzględniony w planach rozwojowych miasta.

\section{KONSULTACJE SPOLECZNE DOTYCZĄCE REWITALIZACJI TERENÓW NADRZECZNYCH W BYDGOSZCZY - CELE, ZAŁOŻENIA I METODOLOGIA}

Zintegrowane podejście do rozwoju miast, zwłaszcza tych leżących nad woda, oraz rewitalizacji terenów nadrzecznych w dużym stopniu dotyczy aspektów społecznych, w tym partycypacji, spójności społecznej i integracyjnej roli tych terenów, planowania, zarządzania i organizacji rozwoju miast nad woda, co wymaga przeprowadzania badań społecznych ${ }^{10}$.

Aktualność problematyki badawczej można przedstawić na przykładzie Bydgoszczy, miasta, którego struktura przestrzenna w silnym stopniu zdeterminowana jest przez unikatowy układ hydrograficzny rzek Brdy i Wisły oraz Kanału Bydgoskiego. Układ ten wraz z rozległymi miejskimi terenami nadrzecznymi w większości zdegradowanymi i zdekapitalizowanymi umożliwia wykorzystanie tego potencjału dla współczesnych potrzeb mieszkańców, a także rozwoju i promocji miasta przez rewitalizację tych terenów.

W artykule zaprezentowano wyniki konsultacji społecznych dotyczących rewitalizacji miejskich terenów nadrzecznych w Bydgoszczy, przeprowadzonych w ramach badań dotyczących rewitalizacji tych terenów w pracy doktorskiej ${ }^{11}$. Głównym celem konsultacji było poznanie opinii rożnych środowisk na temat roli i znaczenia rzeki oraz terenów nadrzecznych w mieście, a także identyfikacja potrzeb i oczekiwań mieszkańców Bydgoszczy w zakresie rewitalizacji i zagospodarowania miejskich tere-

${ }^{10}$ A. Tölle, Przeksztatcanie terenów poprzemysłowych w Berlinie wedtug „dziesięciu postulatów zrównoważonego rozwoju miast nad woda, „Problemy Ekologii Krajobrazu” 24, 2009, s. 101113; idem, Restrukturyzacja miejskich obszarów nadwodnych. Aspekty urbanistyczne, zarzqdzajace $i$ społeczno-kulturowe, Biuletyn Instytutu Geografii Społecznej i Gospodarki Przestrzennej UAM, Seria: Rozwój Regionalny i Polityka Regionalna 10, Bogucki Wydawnictwo Naukowe, Poznań 2010; A. Januchta-Szostak, Rola architektury w ksztattowaniu tożsamości miejskich frontów wodnych, Zeszyty Naukowe Politechniki Poznańskiej, Architektura i Urbanistyka, z. 19, Poznań 2009, s. 119-127; P. Lorens, Rewitalizacja frontów wodnych jako element procesu odnowy miast, w: Przestrzeń w zarzadzaniu rozwojem regionalnym lokalnym, red. K. Markowski, Biuletyn KPZK PAN, 2004, nr 211, PG. 2004, Warszawa, s. 179-205.

${ }^{11}$ D. Muszyńska-Jeleszyńska, op. cit. 
nów nadrzecznych. Konsultacjami objęto tereny nadrzeczne w Bydgoszczy w granicach administracyjnych miasta z 2005 r., położone wzdłuż rzeki Wisły (13,8 km), Brdy (28 km), Kanału Bydgoskiego (6,6 km) i Starego Kanału Bydgoskiego (około $4 \mathrm{~km}$ ). Tereny nadrzeczne były rozpatrywane $\mathrm{w}$ szerszym kontekście, a mianowicie w powiązaniu $\mathrm{z}$ hydrotechnicznym systemem wodnym, będącym osią obszaru badań, oraz w powiązaniu ze struktura przestrzenno-funkcjonalna miasta (mapa 1 i schemat 1 ).

\section{Mapa 1}

Tereny nadrzeczne na tle struktury przestrzennej Bydgoszczy
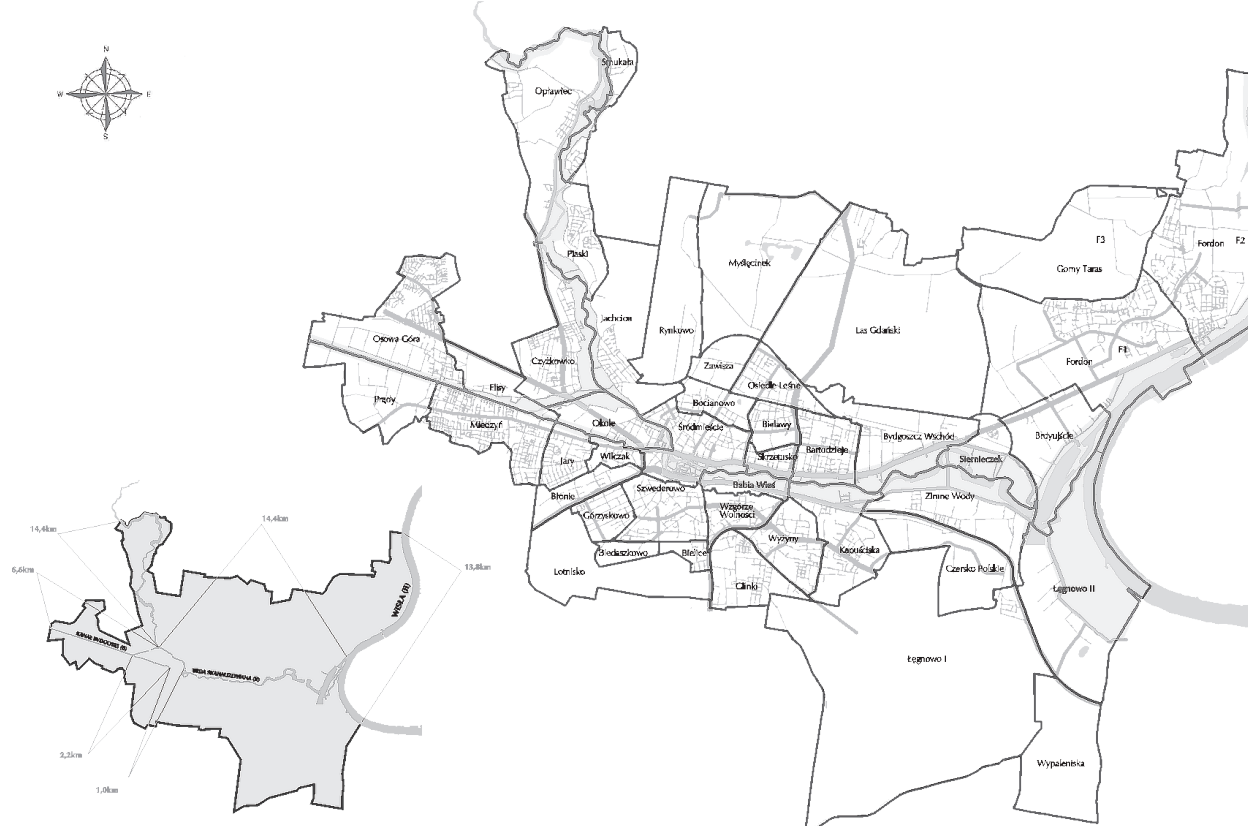


\section{Schemat 1}

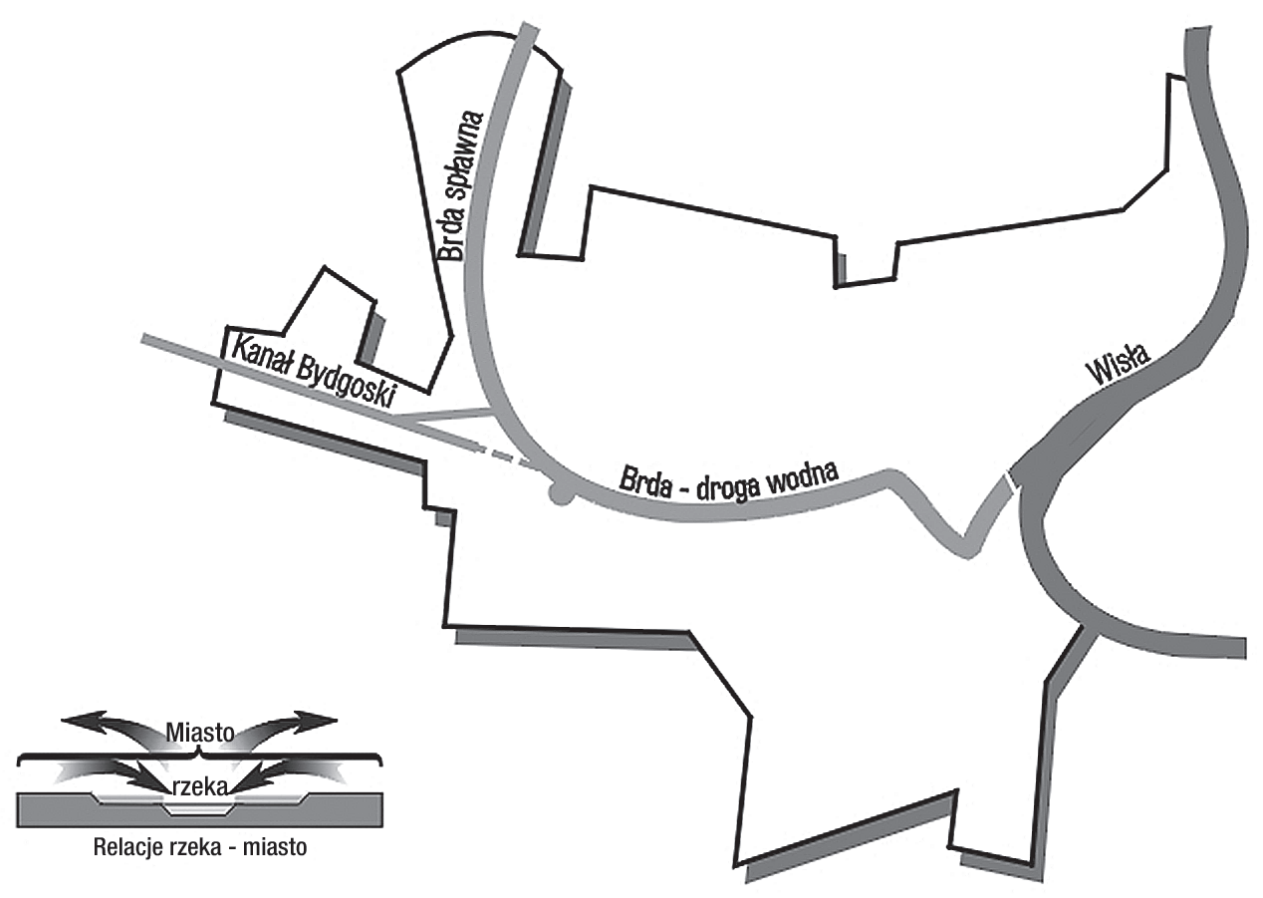

Schemat systemu hydrotechnicznego Bydgoszczy

Źródło: opracowanie własne.

Konsultacje przeprowadzono w styczniu 2011 r. i uczestniczyły w nich trzy grupy badawcze:

1) osoby mieszkające w dzielnicach nadrzecznych Bydgoszczy,

2) osoby będące przedstawicielami instytucji i organizacji „zorientowanych na wodę",

3) przedstawiciele sektora publicznego i prywatnego tworzacy grupę opiniotwórczą.

Podstawowym narzędziem badawczym był scenariusz wywiadu zawierający następujące obszary badawcze oraz pytania szczegółowe:

1) pytania wprowadzajace do problematyki rozwoju i rewitalizacji terenów nadrzecznych w ujęciu ogólnym (Jak zdefiniowalibyście Państwo tereny nadrzeczne?, Z czym kojarzą się Państwu tereny nadrzeczne?, Jak rozumiecie Państwo sformułowanie: Przywracanie rzeki miastu. Miasto frontem do rzeki?);

2) pytania o funkcje tych terenów w przestrzeni miasta, o znaczenie (korzyści), jakie daje obecność rzeki w mieście dla społeczności lokalnej; 
3) pytania odnoszące się do form i sposobów wykorzystywania i użytkowania terenów nadrzecznych przez daną grupę badanych (np.: W jaki sposób postrzegacie Państwo obecność rzek i kanału w naszym mieście, w swojej dzielnicy?, W jaki sposób spędzacie Państwo czas nad wodą?, W jaki sposób wykorzystujecie Państwo tereny nadrzeczne w mieście, w swojej dzielnicy?);

4) pytania dotyczace oceny stanu zagospodarowania i sposobu postrzegania tych terenów w odniesieniu do lokalnej sytuacji w Bydgoszczy (Jak oceniacie Państwo obecny stan zagospodarowania terenów nadrzecznych?, Które tereny/obszary nadrzeczne uważacie Państwo za problemowe, najbardziej zdegradowane, zaniedbane?, Które tereny nadrzeczne postrzegacie Państwo jako atrakcyjne, interesujace?);

5) pytania dotyczące preferencji i oczekiwań osób badanych w stosunku do terenów nadrzecznych w perspektywie ich przyszłego rozwoju i rewitalizacji (W jaki sposób według Państwa można w przyszłości wykorzystać tereny nadrzeczne w Bydgoszczy?, W jaki sposób można zwiększyć atrakcyjność terenów nadrzecznych?, Dla jakich funkcji miejskich atrakcyjne sa tereny nadrzeczne?, Jak powinno wyglądać docelowe zagospodarowanie terenów nadrzecznych w Bydgoszczy?, Jakie obiekty powinno powstać w najbliższym sąsiedztwie Brdy, Wisły i Kanału Bydgoskiego?, Proszę wymienić elementy takiego zagospodarowania);

6) ocena dotychczasowych działań administracji publicznej w zakresie rozwoju i rewitalizacji terenów nadrzecznych w Bydgoszczy oraz wnioski społeczne i rekomendacje dla dalszych działań (Jak oceniacie Państwo politykę i działania władz miejskich związane z rewitalizacją terenów nadbrzeżnych?, Które zadania uważacie Państwo za ważne, istotne, cenne, i które z nich należy kontynuować?, Jakie wnioski należy przekazać włodarzom miast, osobom i instytucjom odpowiedzialnym za rewitalizację terenów nadrzecznych?).

\section{WNIOSKI Z KONSULTACJI SPOŁECZNYCH PRZEPROWADZONYCH W GRUPACH BADAWCZYCH}

Proces konsultacji społecznych dotyczących rewitalizacji rozpoczęło spotkanie z mieszkańcami dzielnic nadrzecznych. W spotkaniu 19 stycznia 2011 r. udział wzięło dwunastu mieszkańców reprezentujących dzielnice Czyżkówko, Miedzyń, Wilczak, Jachcice, Smukała, Opławiec Flisy i Okole. Reprezentowali oni różne grupy pod względem: płci, wieku, zawodu i wykształcenia. W badanej grupie przeważały osoby starsze (zwłaszcza kobiety), w tym emeryci, a także osoby w przedziale wiekowym 25-35 lat, aktywne zawodowo.

W opinii mieszkańców dzielnic nadrzecznych rzeka i tereny nadrzeczne sa dużym potencjałem dla miasta. Zdaniem badanych tereny nadrzeczne wzdłuż rzeki Brdy, pomimo złego stanu ścieżek, coraz częściej są wykorzystywane jako alternatywna trasa poruszania się po mieście, np. dojazdu do pracy rowerem. W badanej grupie osób wielokrotnie podkreślano wartości emocjonalne, 
które dla nich ma rzeka Brda i Kanał Bydgoski, wartości przyrodnicze terenów nadrzecznych, rzadziej jednak ich wartości użytkowe.

W ocenie mieszkańców obecne zagospodarowanie terenów nadrzecznych jest niewystarczajace, brakuje bowiem podstawowej infrastruktury wypoczynkowej i rekreacyjnej w postaci ławek, placów zabaw, odpowiednio przystosowanych ścieżek spacerowych i rowerowych.

Duże znaczenie dla mieszkańców ma bezpieczeństwo przebywania na tych terenach oraz czystość wody i jej otoczenia, dlatego też często zwracali oni uwagę na duże zanieczyszczenie niektórych odcinków Brdy i Kanału, zbyt małą ilość koszy na śmieci, oświetlenia i brak monitoringu.

Uczestnicy panelu, oceniając tereny nadrzeczne, wielokrotnie podkreślali utrudnioną dostępność brzegów rzeki Brdy i Kanału Bydgoskiego oraz zbyt małą ilość przejść i powiązań komunikacyjnych pomiędzy poszczególnymi dzielnicami położonymi na przeciwległych brzegach Kanału. Sytuacja ta dotyczyła Kanału Bydgoskiego i dzielnic z nim sassiadujących (Prądy - Osowa Góra, Flisy - Miedzyń). W czasie dyskusji pojawiały się głosy, że Kanał Bydgoski bardziej dzieli, niż łączy dzielnice położone po przeciwnych jego stronach i jest odbierany jako bariera, którą trzeba pokonać.

Uczestnicy panelu negatywnie oceniali nadbrzeżne zagospodarowanie na wielu odcinkach rzeki, w tym parkingi, strefy magazynowo-logistyczne oraz zaniedbane i niedostępne tereny. Stan ten dotyczy szczególnie terenów nad Brdą na odcinku od hipermarketu Tesco do ujścia Brdy do Wisły. Źle oceniono również stan nawierzchni bulwarów i nabrzeży nad rzeką Brdą. W opinii osób badanych tereny nadrzeczne nie są atrakcyjne ani pod względem zagospodarowania rekreacyjnego, sportowego, ani oferty spędzania czasu nad wodą. Porównywano dzisiejszą sytuacją z różnymi okresami historycznymi, w których zarówno Kanał, jak i Brda czy Wisła były głównym miejscem wypoczynku i rekreacji.

Mieszkańcy za atrakcyjne uznali tereny położone nad Brda spławna (dzielnicę Smukała). Jako uzasadnienie swojego wyboru wskazywali na walory przyrodnicze tego odcinka rzeki, takie jak dzikość brzegów, duży udział terenów zielonych itp. Z drugiej strony uczestnicy doceniaja atrakcyjne zagospodarowanie niektórych fragmentów miasta zlokalizowanych nad rzeka. Najczęściej w tym kontekście wskazywali zrewitalizowane tereny nadrzeczne w centrum miasta, w tym Wyspę Młyńską wraz z otoczeniem Opery, ulicę Mostowa, park nad Starym Kanałem Bydgoskim, bulwary nad Brdą w centrum miasta, Zbiornik Brdyujście z torem regatowym oraz tereny nad Brdą w okolicy Hali Sportowo-Widowiskowej „Łuczniczka”.

Podczas spotkania mieszkańcy bardzo świadomie określali swoje potrzeby, oczekiwania oraz wyobrażenia związane z rozwojem i rewitalizacją terenów nadrzecznych. W opinii badanych rzeka i tereny z nią związane powinny zaspokajać potrzeby rekreacyjne i wypoczynkowe mieszkańców Bydgoszczy w różnym wieku. Tereny związane z rzeka powinny być miejscem rodzinnych oraz towarzyskich spotkań i zabaw. Lokalna społeczność podkreślała też integracyjną rolę, jaką moga pełnić rzeka i kanał w Bydgoszczy. W tym celu powinny być organizowane różne atrakcje przyciagające mieszkańców nad 
Brdę i Kanał oraz umożliwiające spędzanie tam wolnego czasu, np. restauracje i punkty gastronomiczne, kino letnie, plaże, korty tenisowe oraz inne tereny sportowe, wypożyczalnie sprzętu pływającego, fontanny, mała architektura czy też place zabaw. Wszystkie osoby biorące udział w spotkaniu uznały, że w Bydgoszczy miejscem rekreacji związanej z rzeką powinien być Zbiornik Brdyujście. Mieszkańcy chcieliby, aby ta przestrzeń została zagospodarowania na wzór poznańskiej Malty.

W wypowiedziach dotyczących przyszłego zagospodarowania terenów nadrzecznych często podkreślano, że obszary te nie wymagają kosztownych ani komercyjnych inwestycji, a podstawą wszelkich działań nad rzeką musi być poprawa czystości wód oraz uporządkowanie otoczenia rzek i Kanału, poprawa estetyki wielu miejsc nad woda, a także poprawa bezpieczeństwa osób przebywajacych na tych terenach. W związku z poprawą ładu przestrzennego i estetyki badani widzą potrzebę uatrakcyjnienia obiektów przemysłowych zlokalizowanych od strony wody nad rzeką Brdą w okolicach Brdyujścia.

Ważną kwestią dla badanej grupy było również zwiększenie dostępności rzeki, zarówno wzdłuż brzegów, jak i pomiędzy dwoma brzegami rzeki i Kanału. Oczekiwania te dotyczą ogólnie wszystkich, bardzo rozległych miejskich terenów nadrzecznych.

Osoby biorace udział $\mathrm{w}$ badaniu doceniają przyrodniczą wartość górnego odcinka Brdy oraz terenów nadwiślańskich i uważaja, że należy utrzymać te tereny w naturalnej formie, aby zapewnić kontakt z nadrzeczną przyrodą. Uczestnicy wskazywali na konieczność ograniczenia zabudowy na tych terenach oraz wyznaczenia ścieżek przyrodniczo-edukacyjnych, spacerowych i rowerowych.

Zdaniem mieszkańców należy zwiększyć ruch turystyczno-rekreacyjny na rzece przez wydłużenie trasy Bydgoskiego Tramwaju Wodnego aż do Fordonu, uruchomienie połaczenia wodnego w kierunku Ostromecka i Torunia oraz Koronowa w formie regularnych statków wycieczkowych, jednostek spacerowych (gondole, łódki). Uczestnicy badania zaproponowali, aby tereny zlokalizowane wzdłuż rzeki Brdy i Kanału Bydgoskiego pełniły funkcję transportową i stanowiły uzupełnienie ciagów miejskiej komunikacji osobowej, pieszej i rowerowej. Wymaga to odpowiedniego przygotowania i oznakowania oraz urządzenia nabrzézy.

Osoby uczestniczące w badaniu wyraziły wspólny pogląd, że rzeki w Bydgoszczy mogą być magnesem przyciąajacym do miasta turystów. Wymaga to jednak podjęcia działań promocyjnych i popularyzatorskich. W tej sprawie mieszkańcy nie podali jednak konkretnych pomysłów i oczekiwań.

Uczestnicy spotkania licza, że w procesie rozwoju i rewitalizacji terenów nadrzecznych miasto (zabudowa, zagospodarowanie i funkcje) przybliży się bardziej do Wisły, a mieszkańcy będą mogli wykorzystać także walory tej rzeki. Oczekiwania osób biorących udział w badaniu dotyczyły również przystosowania na cele rekreacyjno-sportowe rozległych terenów nad Wisła w Łęgnowie.

W kolejnych spotkaniach konsultacyjnych 26 i 27 stycznia 2011 r. uczestniczyli przedstawiciele środowisk wodniackich oraz instytucji związanych 
z wodą. Wśród uczestników byli kajakarze, motorowodniacy, członkowie klubów związanych ze sportami wodnymi, kapitanowie Żeglugi Bydgoskiej, instruktorzy rekreacji ruchowej, organizatorzy miejskich wydarzeń turystycznych, prywatni przedsiębiorcy prowadzący działalność związaną z turystyka i rekreacją wodną oraz działalnością marketingowa, osoby reprezentujace stowarzyszenia i organizacje pozarządowe związane z Bydgoszczą: Bydgoska Lokalna Organizacja Turystyczna (By-LOT), Stowarzyszenie Bydgoszcz Rowerowa, Stowarzyszenie Juwenkreacja, Muzeum Kanału Bydgoskiego, Towarzystwo Miłośników Miasta Bydgoszczy, Stowarzyszenie Szkoła Przygody „turystyka wodna”. W dwóch spotkaniach konsultacjach udział wzięło łącznie 18 osób.

Opinie grupy przedstawicieli środowisk i instytucji „zorientowanych na wodę" dotyczące terenów nadrzecznych były bardzo podzielone. W wypowiedziach wielokrotnie podkreślano, że z wody widać inaczej. W ocenach uczestników badania rzeka ani jej otoczenie w Bydgoszczy obecnie nie odgrywaja większej roli i nie pełnią ważnych funkcji, a z ekonomicznego punktu widzenia zarówno rzeka Brda, jak i Kanał Bydgoski nie mają znaczenia dla miasta. Ruch na wodzie jest nieznaczny, a rzeka nie generuje znaczących dochodów dla miasta. Wiele wypowiadających się osób doceniło jednak historyczne znaczenie rzeki Brdy i Kanału dla rozwoju miasta jako ważnego portu żeglugi śródlądowej i ośrodka handlowego. Uczestnicy podkreślali, że rzeka jest jednak pewna wartością i istnieje w świadomości społecznej określonej części mieszkańców Bydgoszczy. W wypowiedziach dotyczacych oceny wykorzystywania i postrzegania rzeki jako drogi wodnej, podobnie jak w innych grupach, odwoływano się do historii i czasów, w których życie gospodarcze i społeczne miasta koncentrowało się nad rzeką (druga połowa XIX w. - 1939 r.). Środowiska wodniackie zwróciły uwagę na utylitarne funkcje (głównie turystyczne), jakie pełni rzeka i tereny nadbrzeżne w innych miastach nadrzecznych, takich jak Amsterdam czy Drezno, a które mogłaby również pełnić rzeka Brda i Wisła oraz Kanał Bydgoski (barki mieszkalne, statki wycieczkowe, nadwodne galerie).

Podczas badania fokusowego uczestnicy dość krytycznie odnieśli się do stanu zagospodarowania Brdy, Kanału Bydgoskiego i terenów nadrzecznych na rozległych odcinkach oddalonych od ścisłego centrum miasta. $\mathrm{W}$ ich ocenie obszary te nie są w pełni przystosowane dla aktywnych użytkowników wód, takich jak kajakarze, motorowodniacy i inni turyści wodniacy. Należy jednak podkreślić, że ostatnio wybudowana w centrum miasta marina (Przystań Bydgoszcz) oraz zagospodarowanie śródmiejskich bulwarów nad Brdą wraz z przystankami tramwaju wodnego uczyniło Bydgoszcz (centrum miasta z Wyspa Młyńska) atrakcyjnym miejscem dla wodniaków.

Wzdłuż rozległego szlaku wodnego w mieście nadal brakuje infrastruktury cumowniczej dla różnych jednostek pływających, miejsc postojowych oraz infrastruktury umożliwiającej pokonywanie przeszkód na wodzie (np. przenoski dla kajaków). Zarówno od strony lądu, jak i wody na wielu odcinkach rzeki występuja liczne bariery utrudniające dostęp do wody. Wodniacy zwracali również uwagę na problemy związane z oznakowaniem wód i różnych miejsc w ich otoczeniu, które utrudniają lub uniemożliwiają rekreacyjne i turystycz- 
ne wykorzystywanie wód. Zdaniem uczestników spotkania tereny nadrzeczne nie zachęcają wodniaków do zejścia na ląd z uwagi na nieprzystosowanie nabrzeży, grodzenie terenów przez ich właścicieli, brak atrakcji, nieporządek oraz brak poczucia bezpieczeństwa. W wypowiedziach wskazywano również na ograniczenia w wykorzystywaniu terenów nadrzecznych, spowodowane realizacją nowych inwestycji nieuwzględniajacych potrzeb przyszłych użytkowników. Tereny nadrzeczne negatywnie ocenili również przedstawiciele organizacji rowerowych z powodu niewłaściwego przystosowania nabrzeży do przemieszczania się rowerem wzdłuż rzeki, a tym samym ograniczania ruchu rowerowego na tych terenach.

W badanej grupie podkreślono, że w wielu działaniach miasta widoczne jest myślenie o „rzece” i jej otoczeniu, czego przykładem może być zrewitalizowana i zagospodarowana Wyspa Młyńska, która stała się ulubionym miejscem wypoczynku mieszkańców Bydgoszczy i licznych imprez kulturalnych, tramwaje wodne, bulwary oraz organizacja imprez związanych z rzeka (np. Ster na Bydgoszcz, Wielka Wioślarska o Puchar Brdy i in.). Zdaniem uczestników spotkania jest to właściwy kierunek, który zwraca miasto frontem do rzeki. Wielokrotnie jednak w dyskusji wskazywano na dysproporcje pomiędzy podkreślaniem znaczenia rzek w rozwoju i rewitalizacji terenów nadrzecznych a konkretnymi działaniami w tym zakresie.

Środowiska wodniackie, podobnie jak mieszkańcy Bydgoszczy, mają dużą świadomość swoich potrzeb i oczekiwań względem terenów nadrzecznych. Ich zdaniem sposób zagospodarowania miejskich obszarów nad rzeką w przyszłości powinien uwzględniać rozwój turystyki wodnej. Wskazano na konieczność budowania trwałej infrastruktury dla tej formy turystyki w postaci większej ilości marin z pełnym zapleczem i w odpowiednim standardzie. Zdaniem osób bioracych udział w badaniu wymaga to przygotowania terenów inwestycyjnych oraz stworzenia odpowiedniej dla tych inwestycji oferty miejskiej i jej rozpowszechnienie wśród inwestorów zewnętrznych. Podkreślano także potrzebę wykorzystania i przystosowania istniejącej infrastruktury i zagospodarowania dla potrzeb wodniaków (kajakarzy, wędkarzy, żeglarzy).

W opinii badanych działania modernizacyjno-remontowe i adaptacyjne nie wymagają dużych nakładów finansowych. Zwracano także uwagę na konieczność współpracy i właściwej komunikacji różnych instytucji i jednostek odpowiedzialnych za utrzymanie dróg wodnych (RZGW, Urząd Żeglugi Śródlądowej, Urząd Miasta) oraz współpracy z organizacjami wodnymi. Środowiska te oczekują od samorządu lokalnego koordynacji podejmowanych wspólnie inicjatyw.

W czasie dyskusji zabierali również głos przedstawiciele organizacji pozarządowych. Podkreślano ważną rolę działań prospołecznych, których celem powinno być wzbudzenie zainteresowania mieszkańców rzeką i terenami nadrzecznymi (przebywaniem, odpoczynkiem i spotkaniami nad rzeka), a w efekcie spowodowanie wzrostu popytu na kontakt z rzeką i turystykę wodną. Zdaniem badanych osób znaczącą rolę w tych działaniach powinny odegrać właśnie środowiska wodniackie. Zwrócono również uwagę na możliwość wykorzystania panującej obecnie mody na aktywny sposób spędzania wolnego czasu i w odpowiedzi na te potrzeby przedstawienia ofert i atrakcji nadrzecznych w Bydgosz- 
czy. Dyskutanci wysuwali też propozycje wytyczenia pieszych i rowerowych szlaków turystycznych nad rzekami, uruchomienia rejsów wycieczkowych po Brdzie, Wiśle i Kanale Bydgoskim oraz rozwoju małego biznesu nad rzeka, zwiazanego np. z wypożyczalnią sprzętu wodnego i małą gastronomią.

Środowiska wodniackie, podobnie jak mieszkańcy, oczekują likwidacji barier występujacych na terenach nadrzecznych oraz lepszego dostępu do wody i nabrzeży rzek, np. odsunięcie parkingów od rzeki.

W dyskusji wyrażono także potrzebę opracowania zasad i przygotowania wytycznych dotyczacych przyszłych, nowych inwestycji realizowanych na terenach nadrzecznych, które zapewnią ich właściwą ekspozycję od strony rzeki (zabudowa i zagospodarowanie zorientowane na rzekę). Uczestnicy spotkania podkreślali, że w tym zakresie należy skorzystać z dawnych lokalnych rozwiązań i dobrych praktyk (obiekty przemysłowe i mieszkaniowe zlokalizowane na Wenecji Bydgoskiej - Farbiarnia, Pralchem, tzw. Galeriowiec i in.).

Obecność na spotkaniu przedstawicieli organizacji rowerowych przyczyniła się do wyrażenia oczekiwań tego środowiska związanych z przeniesieniem ruchu rowerowego nad Brdę i budowę odpowiedniej infrastruktury rowerowej wzdłuż rzeki (zwłaszcza na linii E-W). Osoby biorące udział w badaniu zwróciły także uwagę na rolę działań oddolnych i konieczność konsultowania ze środowiskami wodniackimi spraw i działań związanych z rzeką.

Ostatnie spotkanie konsultacyjne odbyło się 17 lutego 2012 r. w grupie przedstawicieli środowisk naukowych, biznesowych (sektora gospodarczego), politycznych (elit politycznych miasta), a także przedstawiciele samorządu lokalnego, instytucji miejskich, radnych Rady Miasta Bydgoszczy, lokalnych mediów i komentatorów życia społeczno-gospodarczego

Uczestnicy spotkania, w odróżnieniu od pozostałych grup, skoncentrowali się głównie na identyfikacji atutów miasta, elementów decydujących o indywidualności Bydgoszczy, będących jej wyróżnikiem, a także na roli i znaczeniu rzeki w mieście i korzyściach, jakie daje miastu.

W opinii badanych osób jednym z podstawowych elementów identyfikujących Bydgoszcz jest jej specyficzne nadrzeczne położenie, „na polanie”, w otoczeniu dużych kompleksów leśnych. Rzeka Brda w sposób wyjątkowy wpisana jest w przestrzeń miasta, co daje obraz miasta osadzonego na rzece czy nanizanego na rzekę („ubrdane miasto”). Kilkakrotnie podkreślano, że wyróżnikiem Bydgoszczy spośród innych dużych miast nadrzecznych jest również wykorzystanie układu hydrograficznego dla potrzeb gospodarczych i społecznych. W tym kontekście odwoływano się do wielowiekowej tradycji gospodarowania terenami nadrzecznymi, polegajaccego m.in. na regulacji rzeki Brdy (kaskadowanie rzeki) oraz zbliżaniu zabudowy i infrastruktury do rzeki i Kanału Bydgoskiego. W opinii badanego środowiska dzięki regulacji Brdy i Kanału Bydgoszcz pozostała przy rzece i jest przykładem miasta, którego układ urbanistyczny (przestrzenny) jest zwrócony do rzeki, ale jego otwartość ograniczaja współczesne (powojenne) inwestycje odnoszące się z „niechęcią do rzeki”.

$\mathrm{W}$ wypowiedziach wielokrotnie podkreślano, że woda i związane z nią nabrzeża, zabudowa nadbrzeżna, zieleń, śluzy, obok kultury i sportu, są wyróżnikiem Bydgoszczy i decydują o tożsamości miejsca. Zdaniem środowisk opiniotwórczych Bydgoszcz wyrosła na Brdzie i jest jednym z tych miast, które rzece zawdzięcza rozwój i większość podstawowych funkcji w swych dziejach 
(handel, rzemiosło). Zwrócono także uwagę na ważne historycznie wielowiekowe związki miasta z rzeka.

W opinii badanej grupy tereny nadrzeczne, zwłaszcza nad Brda, sa zaniedbane i niedoinwestowane. Znaczna część tych obszarów nie jest wykorzystywana. Nad rzeką znajduje się wiele terenów opuszczonych przez różne formy działalności gospodarczej. Doceniono natomiast wyjątkowość funkcji kultury nad rzeka. Wskazano również tereny nadrzeczne, które można uznać za przykład terenów zwróconych frontem do rzeki, np. Wyspa Myńska, Stary Port, Opera, Rybi Rynek.

Uczestnicy dyskusji zwrócili także uwagę na konieczność i sposoby wykorzystania schedy (spuścizny) kultury rzecznej, zaszłości i mitów, energii tkwiącej w rzece, w nowej, współczesnej formie. Zdaniem środowiska opiniotwórczego jest to największy, najcenniejszy potencjał miasta, który należy wykorzystać wielofunkcyjnie i wielowątkowo, tak aby nawiązać do elementów przeszłości. Uczestnicy spotkania dostrzegli możliwość przywrócenia historycznych funkcji rzeki i terenów nadrzecznych w nowej formule symbolicznej, turystycznej, estetycznej. Zdaniem badanych należy również wykorzystać fakt dostępności rzeki do tworzenia przestrzeni społecznych, przestrzeni do życia oraz zagospodarowywania rzeki do różnych funkcji i usług.

Wskazano również na konieczność generowania zachowań rynkowych wokół rzeki i udostępniania terenów nadrzecznych dla strefy biznesu i usług. Pieniądze publiczne powinny być wykorzystane do stymulacji, przygotowania pola działań dla biznesu oraz wprowadzenia funkcji publicznych (generator rozwoju). W dyskusji pojawiały się również głosy dotyczące zwiększenia roli kultury oraz udziału wydarzeń kulturalnych w procesie rewitalizacji waterfrontów. Pojawiła się także propozycja podkreślenia, przywrócenia nadrzecznej tożsamości miasta związanej z barkarstwem.

Zdaniem uczestników spotkania ważnym elementem działań rewitalizacyjnych powinno być uporządkowanie przestrzenno-architektoniczno-estetyczne śródmieścia Bydgoszczy wzdłuż rzeki Brdy. Podkreślono również konieczność uporządkowania i właściwego zagospodarowania terenów nadrzecznych poza centrum (od mostu Pomorskiego w kierunku Brdyujścia) i podjęcia w tym celu współpracy z właścicielami nieruchomości położonych nad rzeką Brda, a także toru regatowego na Zbiorniku Brdyujście.

Zdaniem uczestników spotkania ważne jest również włączenie w proces rewitalizacji terenów nadrzecznych mieszkańców Bydgoszczy oraz tworzenie partnerstwa publiczno-prywatnego.

\section{REKOMENDACJE DLA DZIALAŃ PLANISTYCZNYCH WYNIKAJĄCE Z KONSULTACJI SPOLECZNYCH - UJĘCIE SYNTETYCZNE}

Z przeprowadzonych konsultacji społecznych wynikają następujące rekomendacje dla podmiotów odpowiedzialnych za rozwój i zagospodarowanie przestrzenne miasta: 
1) poprawa czystości wód rzeki Brdy, Wisły i Kanału Bydgoskiego,

2) utrzymanie przyrodniczego charakteru terenów nadrzecznych, zlokalizowanych w górnych odcinkach Brdy spławnej, nad Wisłą oraz ograniczenie na tych odcinkach intensywnej zabudowy i zagospodarowania,

3) poprawa bezpieczeństwa osób przebywających nad rzeką i na wodzie,

4) uatrakcyjnienie wizualne nadrzecznych obiektów przemysłowych,

5) eksponowanie i podkreślanie nadrzecznej lokalizacji przy realizacji nowych inwestycji nad rzeka,

6) uporządkowanie przestrzenno-architektoniczno-estetyczne terenów nadrzecznych,

7) zwiększenie dostępności rzek i terenów nadrzecznych,

8) wytyczenie, urządzenie i wykorzystanie miejskich ciagów transportowych wzdłuż rzek, ścieżek spacerowych i rowerowych,

9) rozwój turystyki wodnej, uruchomienie stałych połączeń rzecznych do Ostromecka, Torunia i Koronowa w formie rejsów wycieczkowych oraz wydłużenie trasy tramwaju wodnego,

10) wypracowanie atrakcyjnych ofert spędzania czasu wolnego i wypoczynku nad rzeką oraz zróżnicowanych, nadrzecznych atrakcji miasta dla celów rekreacji codziennej i weekendowej, powrót do dawnych tradycji spędzania czasu wolnego nad rzeka,

11) przybliżenie miasta do rzeki Wisły,

12) budowa, modernizacja i remont infrastruktury nadrzecznej, a także przygotowanie nadrzecznych terenów inwestycyjnych,

13) generowanie rynkowych zachowań wokół rzeki, rozwój małego biznesu nad rzeka (mała gastronomia, wypożyczalnie sprzętu itp.),

14) konsultowanie planów i zamierzeń z mieszkańcami oraz różnymi jednostkami odpowiedzialnymi za utrzymanie dróg wodnych,

15) aktywność w pozyskiwaniu funduszy na różne działania rewitalizacyjne,

16) podejmowanie działań prospołecznych (oswajanie lokalnej społeczności z rzeka, kultura przebywania na wodzie i nad woda, kreowanie popytu na kontakt z rzeką wśród mieszkańców miasta),

17) wielowątkowe, wielofunkcyjne programy użytkowe, zachowanie różnorodności funkcji terenów nadrzecznych,

18) zwiększenie roli kultury w procesie rewitalizacji terenów nadrzecznych.

\section{PODSUMOWANIE}

Przeprowadzenie konsultacji społecznych pozwoliło na włączenie lokalnej społeczności oraz innych użytkowników rzeki i obszarów nadrzecznych w aktualną i ważną dla Bydgoszczy dyskusję na temat rozwoju i rewitalizacji terenów nadrzecznych oraz nie tylko umożliwiło wybór rozwiąań dotyczących zagospodarowania terenów nadrzecznych, lecz także wskazało na konieczność konsultacji społecznych w rozpatrywaniu problemów rewitalizacji.

Konsultacje społeczne dotyczące rewitalizacji terenów nadrzecznych moga służyć efektywnemu rozwiązywaniu problemów związanych z zarządzaniem 
miastem, a jednocześnie wskazują na konieczność podejmowania w planowaniu działań rewitalizacyjnych współpracy samorządów lokalnych z przedstawicielami nauki, specjalistami różnych dziedzin, a w szczególności z lokalna społecznościa.

Zakłada się, że wyniki konsultacji społecznych mogą być podstawą podejmowania konkretnych decyzji w kwestii kształtowania rozwoju i zagospodarowania terenów miejskich oraz mogą stanowić wytyczne przy opracowywaniu miejscowych planów zagospodarowania przestrzennego.

Zwrócenie uwagi na potrzebę prowadzenia procesów rewitalizacyjnych wspólnie z mieszkańcami jest kluczem do sukcesu. Metody i rozwiązania wypracowane wspólnie z nimi (w uspołecznionym procesie rewitalizacji i planowania przestrzennego) służą do kształtowania nowej przestrzeni w pełni czerpiącej zarówno z potencjału danego miejsca, jak i ludzi.

Rewitalizacja terenów nadrzecznych umożliwia otwarcie tych terenów na funkcje publiczne, zapewnia ogólną dostępność do rzeki, poprawiając jednocześnie jakość życia mieszkańców miasta i ich wypoczynku, a także przyczynia się do właściwego kształtowania relacji przestrzenno-funkcjonalnych rzeki $\mathrm{z}$ miastem.

dr Dominika Muszyńska-Jeleszyńska

Uniwersytet Kazimierza Wielkiego w Bydgoszczy

dominika.muszynska@ukw.edu.pl

\section{THE IMPORTANCE OF PUBLIC CONSULTATIONS IN THE PROCESSES OF URBAN REVITALISATION}

Summary

The article presents methods of conducting public consultations on the regeneration of urban riverside areas and their results, and also justifies the need for research in this field. This issue relates closely to Bydgoszcz, a city that is located on the Vistula and Brda rivers and the Bydgoszcz Canal. The rivers form the hydrographic axis of the city and define its public space. The article discusses the methodology adopted for public consultations which play an important role in determining the direction of riverside land development and use. The public consultations were carried out within the framework of the author's doctoral dissertation entitled 'The riverside areas in the spatial and functional structure of Bydgoszcz. Problems of development and regeneration.' 
